\title{
The labors of justice: democracy, respect, and judicial review
}

\author{
Jeffrey W. Howard ${ }^{1}$ \\ Department of Political Science, University College London, UK
}

\begin{abstract}
Why value democracy? One familiar answer is that democracy expresses respect for citizens, whereas nondemocratic modes of governance insultingly express disrespect. Recent work has subjected this view to substantial criticism, raising serious doubts about its plausibility. This article contends that prevailing objections succeed only because they target implausible interpretations of this view, according to which the wrong of political exclusion consists in some insulting disregard for the interests of excluded agents. On the revised respect-based argument to be defended here, however, the insult of political exclusion implicates not the interests of excluded agents, but rather their duties. On this view, democracy is uniquely respectful because it recognizes that the work of achieving a just political order is work that morality assigns not simply to a select few, but to all. To shut moral agents out of the decision-making process is insulting because it flouts their status as the kinds of beings on whom duties of justice equally fall, and who therefore have a presumptively equal prerogative to be involved in seeing to it that justice is done. This interpretation of the respect-based argument is not susceptible to the objections advanced against other interpretations. It better accounts for the role of reasonable disagreement about justice in democratic theory. And it is superior at explaining why respect-based democrats should harbor a qualified skepticism toward judicial review: because the job of securing justice fundamentally belongs not to judges, but to everybody.
\end{abstract}

\section{KEYWORDS}

Democracy; respect; natural duty of justice; judicial review

\section{Introduction}

Why should liberals endorse democracy? Why, that is, should those committed to the ideal of liberal justice believe that democracy is the appropriate manner in which to govern their political arrangements? One answer contends that democracy is a valuable mode of decisionmaking because it expresses respect for moral agents, whereas non-democratic modes insultingly express disrespect. But this answer, while initially alluring, is mysterious upon reflection. Why should citizens feel disrespected or insulted if their exclusion from the political process does not leave them or indeed anyone worse off from the standpoint of liberal justice? Especially if liberal justice would be better served by excluding certain people

\footnotetext{
${ }^{1}$ jeffrey.howard@ucl.ac.uk
} 
from politics, or by granting them less of an opportunity to influence political decisions than others, what kind of complaint could such persons possibly have?

These questions are persuasively pressed in Niko Kolodny's recent assault on modern democratic theory, which outlines a variety of interpretations of the respect-argument, contending that each fails (2014a). When we consider the reasons why a citizen might take herself to be insulted ${ }^{\mathrm{i}}$ when excluded from the political process, none furnish an adequate basis for democracy's value. Consider just three of the potential reasons that Kolodny canvasses: ${ }^{\text {ii }}$

a) Your Substantive Interests Don't Matter: exclusion is disrespectful because it suggests that excluded agents' interests are not to be granted equal weight in the determination of the law. ${ }^{\text {iii }}$

b) You Will Probably Vote for Injustice: exclusion is disrespectful because it suggests that excluded agents are likely to make bad decisions-most notably, by voting for unjust legislation or officials who support it. ${ }^{\text {iv }}$

c) You Don't Understand Your Own Interests: exclusion is disrespectful because it suggests, paternalistically, that excluded agents are unfit to make decisions about their own interests.

Kolodny rightly notes that none of these alleged insults convincingly grounds the case for democracy. Your Substantive Interests Don't Matter errs because it is perfectly possible to defend a non-democratic form of governance on the basis that excluded agents' interests would be better served by such deviation, as traditional arguments for colonialism held. And while it is surely true that non-democratic arrangements may well be worse at securing liberal justice than democracy is, this is a contingent, not necessary, fact. Insisting that nondemocratic forms of governance necessarily rest on the argument that excluded agents' interests do not matter is thus clearly mistaken. 
Similarly, absent further argument, You Will Probably Vote for Injustice fails to supply a good argument for democracy. It is not obviously objectionable to communicate to someone that she is unlikely to support just policies (2015a, p. 219), especially when the judgment is justified. Finally, You Don't Understand Your Own Interests is plainly a nonstarter: those who wish to disenfranchise people on the grounds that they will make bad decisions about justice are not making a judgment about those persons' capacity to pursue their own good successfully. Critics of democracy, then, need not be paternalistic.

Is there anything, then, to be said for the respect-based argument? I believe that Kolodny's objections succeed only because they target implausible versions of the argument. Once a more attractive alternative is specified, we will see that it less vulnerable to the objections that afflict its cousins. To explain the value of democratic government, I will argue, we need to remember what government is properly for: the achievement of a just society. And it is democracy alone that recognizes that the job of achieving a just society is one that morality assigns not to a select few, but to all. That is why it is uniquely respectful.

In the next section, I offer an initial sketch of this radically different version of the respect-based argument. In the subsequent two sections, I elaborate the argument in order to defend it from some objections. And in the final section, I test-drive the account by showing how it offers plausible guidance on one of the most significant debates in democratic theory: on the role of judicial review. My aim is to identify and explore a crucial but overlooked pro tanto reason why liberals are rightly attracted to democratic government. While an all-thingsconsidered argument for democracy is beyond the scope of this article, I hope to show that the respect-based argument has greater promise-and merits greater attention-than commonly supposed.

\section{Respecting citizens as agents of justice}


The seed for this alternative interpretation of the respect-based argument is planted, surprisingly, by Jeremy Waldron. This is surprising because Waldron explicitly defends two of the other interpretations dismissed above-Your Substantive Interests Don't Matter and You Will Probably Vote for Injustice (1999, e.g., on pp. 238-39). But he also briefly intimates a very different sort of story — one that Kolodny and other scholars have neglected:

People owe each other certain fundamental duties of respect and mutual aid which are better fulfilled when orchestrated by some central agency like the state than when they are left to the whims of individuals. But since it is my duties (among others') whose performance the state is orchestrating, I have a right to a say in the decision-mechanisms which control their orchestration (2000, p. 234, emphasis added).

What sort of argument does Waldron have in mind here? He does not elaborate, leaving this suggestion behind, so we will need to develop this idea independently of any further engagement with his text.

Here, roughly, is the argument as I imagine it. Following the main currents of neoKantian liberal political philosophy, let us stipulate that all moral agents are subject to a natural duty of justice: to promote the achievement and maintenance of liberal justice, both at home and abroad. ${ }^{\mathrm{v}}$ The general implications of this duty are well understood: those living under just institutions have decisive moral reason to maintain those institutions; those living under unjust institutions have powerful moral reason to reform, or abolish and replace, those institutions, ${ }^{\mathrm{vi}}$ and those living under no political institutions have powerful moral reason to create them and render them just. ${ }^{\text {vii }}$

What, exactly, is the work that agents need to accomplish in order to establish and maintain just institutions? These central labors consist in the determination and enforcement of law. Positive law is required to secure what liberal justice demands for two familiar reasons. First, it takes abstract moral requirements of liberal justice-requirements subject to indeterminacy and reasonable disagreement — and focuses them into determinate legal duties that are binding on all. Second, positive legal systems enforce those determinate duties, thereby deterring people from undermining the achievement of justice and providing agents 
with assurance that their efforts will not be futile or unfair. These legal provisions will not establish themselves. The work of establishing them - the work of government- has to be done by somebody. ${ }^{\text {viii }}$ The question, then, is: to whom does the work belong?

Because the natural duty of justice is a natural duty, it applies to all moral agents. No agent is exempt from the duty because of her race, or religion, or gender, or sexual orientation, or differential talents; nor is anyone subject to a different (e.g., more stringent) version of that duty, in virtue of such morally arbitrary features. The duty falls on each and every one of us. That means that moral agents are, with respect to the natural duty of justice, jointly tasked with promoting the achievement and maintenance of just institutions. To view one another as bearers of the natural duty of justice is to view the labors of justice as ones jointly assigned to all. And for those who share a polity, that means they as members are jointly tasked with the job of creating or otherwise maintaining political structures that assure justice for all.

What form of governance instantiates the moral idea that citizens are jointly tasked with authoring just legal relations among themselves? The answer is: a form of governance that recognizes and institutionalizes that joint moral responsibility in its default allocation of decision-making authority. The answer is democracy. When we ask ourselves the central question of democratic theory_why should members of the political community be jointly tasked with the job of pursuing justice? - this argument offers an arrestingly simple answer: because justice itself already assigns them that task.

This account furnishes us with a new story about why political exclusion seems insulting. The distinctive wrong of political exclusion is that it disrespects people as bearers of the natural duty of justice. It denies them their presumptively equal, morally assigned seat at the table at which the labors of justice are debated and decided. To shut certain people out of the decision-making process, however, is to suggest that it isn't their work; it is to respond 
to such agents' demand for political inclusion with a simple slogan: "This isn't your business." But that slogan is mistaken: it suggests, falsely, that those excluded from democratic participation are not members of the community of agents on whom duties of justice fall.

More precisely, excluding moral agents from the political process is prima facie wrong because it disrespects their moral capacities. Now the kind of respect I have in mind is not what Stephen Darwall famously calls appraisal respect, which involves "a positive appraisal of a person or his character-related features" (1977, p. 41). Acting on the judgment that an agent has objectionable beliefs about justice, we observed earlier, is not necessarily disrespectful, especially when the judgment is justified. So what I am referring to here is recognition respect, which "consists in giving appropriate consideration or recognition to some feature of its object" (p. 38). The object in question is the moral agency of agents themselves. More specifically, it is a particular aspect of their moral agency - their capacity for justice.

Consider the widely influential idea that moral agency consists in the possession of two moral powers: first, a capacity to reason about justice and regulate one's conduct by the conclusions of that reasoning; and second, a capacity to frame and pursue a conception of the good (Rawls 2005, pp. 47ff). Liberal theorists have lavished attention on what it is to disrespect agents' second moral power (e.g., Shiffrin 2000, Quong 2011, p. 80). Paternalistic policies, for example, are objectionable not because they fail to express appropriate appraisal respect; after all, agents are often irrational. Rather, paternalistic policies are objectionable because they fail to respond appropriately to the very existence of the capacity of agents to pursue their own good. They fail to respect the second moral power as a matter of recognition respect. 
Liberals insist that respect for moral agency is a central value. If that is so, then it cannot simply be the second moral power that we are obliged to respect; we have to respect the first moral power, as well. But liberal theorists have not spent much time addressing what is required by respect for the first moral power. ${ }^{\mathrm{ix}}$ My thesis is that one powerful reason for favoring democratic political arrangements over non-democratic arrangements is that democracy expresses respect for citizens' first moral power. It recognizes them as bearers of duties of justice.

How, exactly, does a democratic political order, suitably designed, respect citizens' first moral power? First, it insists that all moral agents be granted a set of democratic rightsof speech, association, and participation — through which to exercise their first moral power. Second, in insists upon a public culture that views political participation not simply as a right to be exercised in order to pursue their own self-interest, but even more importantly a responsibility they owe to others. ${ }^{\mathrm{x}}$ Denying racial minorities and women the franchise was objectionable not simply because it prevented them from advocating for their own interests, ${ }^{\mathrm{xi}}$ but more fundamentally, because it signaled that the great challenges of public life were not theirs. Finally, democracy respects all agents' first moral power by insisting upon presumptively equal opportunity for political influence-thereby instantiating the idea that the natural duty of justice binds all as moral equals.

This interpretation of the view is importantly distinct from the other interpretations of the respect-based argument. First, it does not rest on the idea (as "Your Substantive Interests Don't Matter" does) that political exclusion implies the excluded agents' interests do not matter. Even if other forms of governance could promote agents' interests as well as democracy, we have powerful respect-based reasons to opt for the latter. Second, it does not rest on the idea (as "You Will Probably Vote for Injustice" does) that it is disrespectful to express a lack of optimism in others' moral capacities. Optimism has nothing to do with it; 
political exclusion is disrespectful simply because others have moral capacities, triggering the applicability of the natural duty of justice. Even if an agent is unlikely to live up to a duty he has, this does not exempt him from that duty. A duty does not disappear simply because an agent is unlikely to fulfill it. Third, the view does not allege (as alleged by 'You Don't Understand Your Own Interests") that political exclusion insults citizens' capacity to pursue their own good. Rather, it insults citizens by suggesting that they are not to be considered agents of justice - and thus by failing to recognize that the labors of justice are theirs to complete.

Even if we grant the argument so far-that democracy expresses respect for citizens' first moral power-this view faces some important questions. First, surely democratic citizens should be prepared to deviate from democratic decision-making-e.g., outsourcing political decisions to unelected bodies - if they judge that justice would be better served in so doing. Does the respect-based argument license such deviations? Second, if advancing justice is what matters, then surely we can expect those who are better positioned to advance justice to play a greater role. Does the respect-based argument license the possibility of differential contribution? In elaborating the respect-based argument in the next section, I will defend qualified but broadly affirmative answers to both of these queries. I will then explore the issue of when deviations are justified in greater detail. Far from undermining the democratic credentials of the theory, these refinements will reveal the kind of democracy that all have reason to want: a democracy justified and structured by a singular mission, of securing justice for all.

\section{Refining the respect-based argument}

Because the natural duty of justice is at the heart of the account, it gives guidance to the sort of democratic ideal to which we ought to aspire. Here I want to focus on two particular ways 
it does so. First, it explains why citizens' prerogative to participate in politics is defeasible. When justice is best served by deviating from democracy, this can, in principle, be justified. And second, it explains why citizens' prerogative to participate in politics is variably demanding — depending on the costs faced by different agents.

\section{Democracy as defeasible}

Suppose that democracy is (at least partly) grounded in respect for citizens' status as agents of justice, as the respect-based argument holds. If that is right, we must not defend the idea that decisions should be made democratically no matter what. Instead we must defend a more plausible idea: that democracy is a default rule - a rule to which we standardly defer provided there is no compelling justification for deviating from it in the case at hand.

If citizens would retard, rather than advance, the achievement of justice by making the decision democratically when there is an alternative mechanism available, they ought to opt for the alternative. And if they view themselves as responsible for advancing justice, as they surely should, they cannot complain of being disrespected when circumstances arise that render this appropriate.

Consider a salient example: national banks. Monetary policy is standardly taken out of the hands of the ordinary democratic process and assigned to a group of experts. The rationale is clear: while such decisions clearly concern the basic structure of society, and so are presumptively the concern of all, they will (the rationale goes) be better made through a process that deviates from the democratic default. Moreover, while the creation and maintenance of national banks has largely been traceable to decisions by democratically elected representatives - the U.S. Federal Reserve System was created by an act of the U.S. Congress in 1913 and its chairman continues to be appointed by the American president-it is misleading to suggest that individual decisions taken by the Federal Reserve Bank are 
therefore "made democratically." They are not. Rather, the decisions of monetary policy are deliberately taken outside of democratic hands so that they can be made by those who know better.

Is this inherently objectionable? It surely is if we hold an interpretation of the respectbased argument-like "You Are Likely to Vote for Injustice"- that makes it an insult ever even to suggest that some are unlikely (say, due to lack of knowledge of economics) to make bad decisions. But for a theory grounded in the natural duty of justice, there is nothing inherently objectionable here. It all depends on whether this deviation from the democratic default rule genuinely serves the aims of liberal justice or not. ${ }^{x i i}$

If bearers of the natural duty of justice morally ought to deviate from democracy (specifically, ought to authorize and comply with deviations from democracy) when doing so serves the aims of justice, it is implausible to think that such deviations express disrespect for them. While respect for persons demands that all members of the society have a presumptively equal role in decision-making, they must be prepared to accept a substantially weaker role for those particular decisions that are better made by experts. To deny this would be to fetishize political participation, objectionably, over the achievement of justice.

Hypothetically, deviations from democracy could be justified on a permanent basis. If we had excellent reason to believe that authorizing non-democratic institutions to make political decisions would yield more just outcomes, this would be justified. But it is difficult to accept that the natural duty of justice would license permanent deviations in practice. That is for a wholly uncontroversial reason. All human beings are fallible. It would be morally irresponsible to outsource decisions to others without allowing any opportunity to review those decisions in the future and reconsider them. Accordingly, democratic citizens must view themselves as retaining the prerogative to dispense with outsourcing the moment they judge it to turn against the cause of justice. 
The fact of pervasive fallibility also helps explain why deviations from the democratic default should, as a general presumption, be made democratically. Moral emergencies aside, we should favor a standing prohibition on efforts by private individuals to seize the reins of government power by force in order to issue new legal directives, even if those directives are, in fact, wise. No citizen, concerned about the achievement of justice, should tolerate gangsters appointing themselves guardians - even if they avow to be only temporary, and even if they genuinely possess expertise that was likely to enable them to advance the cause of justice. To be sure, history works this way at times, albeit in less dramatic fashion; courts illegitimately arrogate authority to themselves that they were originally not conferred by the democratic polity. ${ }^{\text {xiii }}$ But this simply presents citizens with the question of whether they should accept such deviations as ones they already had reason to pursue, or instead work to overturn them.

\section{Democracy as variably demanding}

The natural duty of justice also explains why it would be a mistake to expect all moral agents to pursue the exact same courses of action in their activities as citizens. The fact that the natural duty of justice falls on every moral agent - and so applies to all as moral equalsdoes not mean that the specific courses of action it demands are the same for every moral agent. The specific demands of the natural duty of justice are sensitive to the costs it poses on individuals (Rawls 1999, p. 294). The natural duty of justice is, after all, a duty justified on deontological, rather than consequentialist, grounds; it does not expect agents to sacrifice their most basic interests for others in the way a utilitarian account, for example, would demand. Its requirements must not be unreasonably burdensome.

In a democracy, then, citizens' morally assigned portfolios will be greater or smaller depending on how costly it is for citizens to undertake the work. So while citizens in a 
democracy are equipped with the same powers of participation-to speak, associate, and vote-different citizens may reasonably be expected to marshal those powers to different degrees, depending on the costs. This is especially so in contexts of serious socioeconomic injustice, in which full-throated democratic participation is costly for some people only because they have been deprived of the resources to which they are morally entitled. It is reasonable to expect greater efforts engaging in political activism, writing op-eds, petitioning public officials, deliberating with co-citizens, and so on, from those for whom such activities are less costly.

It might be suggested that, for certain moral agents, the costs of political participation are so great that it is never reasonable to expect them to engage in any activities aimed at the establishment and maintenance of justice. All that is reasonable to expect of them is simply to comply with just laws, should they happen to exist. ${ }^{\text {xiv }}$ Now this could be possible in seriously unjust states, such as totalitarian regimes, in which citizens face considerable threats to life and limb by engaging in any political resistance. However, in the context of modern democratic societies such as the United States and the United Kingdom, it is difficult to believe that there is a determinate group of bona fide moral agents for whom it is unreasonable to expect any efforts to advance justice beyond mere legal compliance. Even if it would be unreasonably costly to expect disadvantaged citizens to dedicate the same resources as their more advantaged compatriots to civic activities, such citizens still have a minimal but vital role to play in the struggle for justice. ${ }^{\mathrm{xv}}$ But even if not, it is instructive to note that the kind of crippling disadvantage that would altogether exempt an agent from the labors of democratic politics would be absent in the kind of society toward which the natural duty of justice requires we strive - a society that secured adequate education, opportunity, and resources for all. 
It might instead be suggested that even in a just society, some citizens are so fundamentally flawed at reasoning about justice that mere legal compliance is all that could reasonably be expected of them. It is too costly, we might think, to expect them to do the work required of responsible democratic citizenship. Even so, there are powerful reasons to doubt that revoking the democratic rights of such persons would be the right response to this fact. Even if the work of democratic citizenship is so costly for some that it could not reasonably be expected of them at all—something I seriously question-it is implausible that we could bifurcate the population of moral agents into those for whom democratic citizenship is too demanding and those for whom it is not. It is much more plausible to think that it is differentially demanding for different people at different times, depending on their knowledge of the particular issues at stake in a particular election and what else is happening in their lives. When democratic engagement becomes too costly, agents should feel free to refrain from exercising their democratic powers in such instances.

Of course, some citizens do not simply refrain from exercising their democratic powers. Some citizens exercise their democratic powers badly, voting for unjust policies and advocating for unjust causes. Still, so long as it is not too costly to demand of such citizens that they exercise their democratic powers well, we ought to view them as duty-bound to do so. If we accept that an agent has a certain duty, the discovery that the agent is unlikely to live up to that duty does not render him suddenly off the hook. A more familiar response is to insist that he do his duty-remonstrating with him, persuading him, educating him, condemning him - and, in the end, preventing him from doing injustice should our deliberative efforts be unsuccessful. Below I argue that rights-based judicial review, of a certain variety, could serve as such a form of prevention. But to suggest that we could mark out particular people as enduringly fated to vote for injustice - and so strip them of their vote accordingly—is implausible. 
More fundamentally, to condemn a bona fide moral agent as hopeless to such an extent as to conclude that he should not even be granted powers of democratic citizenshippronouncing with confidence that he will never live up to his moral duties-effectively amounts to denying that he even possesses the first moral power. If he is a moral agent - if he is the kind of being who can be said to have duties, and to be blamed for failing to discharge them—-such denial is seriously disrespectful.

\section{Justifying democratic deviations: the role of disagreement}

\section{The disagreement-insensitive respect-based argument}

The purpose of a default decision rule is to set the normal mode of decision-making. Only if there is good reason to deviate from the default ought the deviation occur. So we need to know what, exactly, counts as a justification for deviating from democratic decision-making. In the last section I said that advancing the cause of justice furnishes precisely that justification; a citizen would be betraying her natural duty of justice if she resisted deviation in such a case. This seems straightforwardly to yield the following principle (whose name will become sensible soon enough):

Disagreement-Insensitive Deviation Principle. A deviation from the democratic default rule is justified if it advances the achievement of justice.

The crucial question, then, arises in evaluating what it is to advance the achievement of justice.

Here the argument faces a crossroads. There are, I propose, two different ways in which the respect-based argument could specify when, exactly, deviations are morally permissible. Each, in turn, yields a subtly but importantly different version of our respectbased argument. I will call the first version the disagreement-insensitive respect-based 
argument; I will call the second version the disagreement-sensitive respect-based argument. I'll spend the rest of this section sketching out these two versions.

The first path is to follow the aforementioned principle straightforwardly: to argue that when a deviation from democracy will serve the aims of justice, it is justified. A deviation is justifiable just in case it actually advances the cause of justice. The fact that some might disagree with the claim that the deviation advances justice—say, because they hold a different view of what justice demands - is beside the point. This view is disagreementinsensitive because claims about what people disagree about, or could reasonably disagree about, play no role in the determination of when deviations are justified.

To bring this view into sharper focus, consider how it handles the following objection. It might be suggested that even if a deviation from democracy advances the cause of justice, such a deviation is disrespectful. Even when a democratic decision is unjust, perhaps the fact that it was made democratically means that it retains pro tanto moral value and sopotentially - ought to be respected. According to this objection, what we ought to do in such a case is to weigh the value of the decision's democratic pedigree against the disvalue of its substantive injustice. This argument is defended explicitly by Corey Brettschneider, who argues that "the democratic authority of a law still retains some normative force even when it undermines these substantive values [of liberal justice]" (2011, p. 3).

However, this way of thinking is implausible in the context of a theory grounded in the natural duty of justice. Citizens' prerogative to participate in politics is only prima facie justified, not pro tanto justified. On my view, an agent's political participation has no value when marshaled to advocate for injustice. What has value is the genuine exercise of moral agency — the operation of the first moral power. The decision to enact injustice cannot qualify as a genuine exercise of the first moral power at all; if anything, it reflects a corrupted and subverted form of that power, or even an abdication of it. ${ }^{\text {xvi }}$ Thus citizens who are prevented 
from implementing unjust legislation cannot sensibly claim that their first moral power was disrespected by such prevention. Once we commit ourselves to the idea that the purpose of democratic structures is to serve justice, such structures' operation cannot have value when they turn against justice. ${ }^{x v i i}$ That is so even if citizens themselves think that the laws they have democratically enacted are just. What matters, ultimately, are whether they are in fact just.

This disagreement-insensitive version of the respect-based argument is straightforward and attractive. It is itself a novel position in democratic theory worthy of development. It has especial appeal to those who are dismayed by the considerable focus on disagreement in liberal political theory, believing instead that the phenomenon poses no significant philosophical problems. My own inclination is that reasonable disagreement about justice poses theoretical difficulties for this simple version of the respect-based argumentdifficulties that motivate the specification of a second, more complex variation. Those who disagree can feel free, of course, to embrace the simpler version that this article has, until this point, defended. In the remainder of the article, however, I will develop the more complex, disagreement-sensitive version of the view.

\section{The disagreement-sensitive respect-based argument}

Some people are simply mistaken about what justice requires, to be sure. And when they are simply mistaken about what justice requires, they are not disrespected when their will is overturned. That much the disagreement-insensitive view has exactly right. The trouble arises when the disagreement is reasonable. For, I will argue, when citizens reasonably disagree about the truth of a particular issue about justice, democracy remains the respectful mode of settling that disagreement. Outsourcing the decision to non-democratic institutions is, I will argue, objectionable in such cases. 
What is it for a disagreement to be reasonable? One possibility, which I reject, holds that a disagreement is reasonable just in case each party to the disagreement is subjectively justified - justified in light of her evidence — in holding the belief that she does. On this view, a disagreement over whether slavery is morally permissible could qualify as reasonable just in case the slavery-defender's epistemic vantage point was so distorted that it was subjectively reasonable from her to conclude, on the basis of the evidence available to her, that slavery is morally permissible. But this is not what liberal political theorists have in mind when they speak of reasonable disagreement about liberal justice. ${ }^{\text {xviii }}$ The fact that an agent is subjectively reasonable in believing that it is morally justified to oppress others plainly does not grant her a moral permission to oppress others. ${ }^{\text {ix }}$ The reasonableness of a disagreement, then, cannot be a simple function of whether both parties to the disagreement are reasoning in a subjectively justified fashion.

On the interpretation of reasonable disagreement that I shall employ here, a disagreement can be objectively reasonable. What makes a disagreement over a policy reasonable, on this view, is that the arguments for and against the policy are comparably plausible. As Rawls describes this phenomenon, citizens who "share a common human reason" and hold "similar powers of thought and judgment"- - who are equally equipped to "draw inferences, weigh evidence, and balance competing considerations" and have access to the same pool of the best evidence available — nevertheless arrive at different positions on the question under discussion (p. 55). As the common saying goes, a reasonable disagreement is one in which there are good arguments on both sides. ${ }^{\mathrm{xx}}$

There are, of course, reasonable disagreements about all sorts of subjects. Our concern here is reasonable disagreement about the demands of liberal justice. The idea that there can be reasonable disagreement about the demands of justice is not a controversial one in liberal political philosophy. Arguably the discipline itself is a testament to idea that those 
who reason well and have access to the same evidence nevertheless arrive at different answers to the same questions. The history of liberal political philosophy is filled with recognition of the phenomenon. For John Locke, it is partly because intelligent people are bound to come to differing interpretations of the natural law that it is rational for them to exit the state of nature and empower an authority to settle their disputes $([1689] 1980, \S 13,21) .{ }^{\mathrm{xx}}$ For Immanuel Kant, exiting the state of nature is not merely rational, but morally compulsory - precisely because conscientious agents' private judgments about what justice requires will diverge [1797] 1996, §44).

Kant's argument is instructive for our purposes. For him, reasonable disagreement about justice is problematic with respect to justice itself. Without an authoritative interpretation of the demands of justice — specified and enforced by positive law-different agents are apt to enforce their own views about what justice requires. ${ }^{\text {xii }}$ A world with such conflicting patterns of enforcement is deeply morally undesirable from the perspective of justice. ${ }^{\text {xiii }}$ So, too, is a world in which we respond to reasonable disagreement about justice by doing nothing - by refusing to take a collective stand on what to do. Jonathan Quong illuminates this exact issue:

Suppose, for example, that justice requires the state to enforce one regime regarding property rights from the set (P1, P2, P3, P4), but citizens are evenly divided regarding which regime from the set is in fact required by justice. Further suppose that a world where the state fails to enact any of the property rights regimes (i.e. it does not enact any of P1-4) will be far less just than a world where any one of P14 are enforced. ${ }^{x x i v}$

Quong's contention is that citizens ought to prefer some reasonable solution from the set to be selected as the official property scheme, even if their preferred solution is not selected. Indeed, they see themselves as morally required by justice to opt for some reasonable solution in the face of disagreement; otherwise, ex hypothesi, their society would become "far less just," a result that is morally unacceptable. Indeed, it is precisely the natural duty of 
justice that should move them to insist that some reasonable interpretation of the demands of justice be implemented.

I reiterate: those who deny that there is such a thing as reasonable disagreement about justice can simply help themselves to the disagreement-insensitive version of the respectbased argument sketched earlier. On that view, deviations from democracy are justified whenever they advance the cause of justice. But for those who take reasonable disagreement about justice seriously, such disagreement raises a complication. For, in an important range of cases, what counts as moving toward justice according to one reasonable position in a debate would count as moving away from justice according to another reasonable position in that debate. ${ }^{\mathrm{xxv}}$ For example, consider whether justice requires that citizens be granted exemptions from laws that burden their religious practices. Assume for the sake of argument that this question is subject to reasonable disagreement. Suppose an agent attempts to justify a deviation from democracy on this issue, on the grounds that citizens would likely enact a policy of exemptions and that such a policy is unjust. Clearly those who reasonably disagree that the policy is unjust would reject this argument for deviation. Accordingly, it is difficult to see how the deviation would be morally required; after all, ex hypothesi, the issue is indeterminate. There are plausible arguments on both sides.

In cases of reasonable disagreement, I believe that deviating from democracy to advance one of the reasonable contenders in the debate cannot be justified. Citizens rightly regard themselves as disrespected when the democratic process is shut down, or overridden, to prevent their reasonable view about what justice requires from becoming law. Earlier I said that we do not disrespect citizens' first moral power when we prevent them from enacting undeniable injustice, because their first moral power isn't doing its job if injustice is what they are advocating. In cases of reasonable disagreement, however, it is not true that those on 
one side of the dispute are misusing their powers of agency. Their arguments are just as good as those on the other side.

We arrive, then, at:

Disagreement-Sensitive Deviation Principle. A deviation from the democratic default rule is justified if it is beyond reasonable dispute that such a deviation would advance the achievement of justice.

What would it take for a case for deviation to be beyond reasonable disagreement? First, the policies that the deviation serves to prevent have to be unjust beyond reasonable dispute. Second, the claim that such injustices would reliably be avoided through the deviation itself also needs to be beyond reasonable dispute.

David Estlund considers this second issue when reflecting on why an "epistocracy of the educated" would be morally impermissible, so it is instructive to see what he has to say. Estlund's task is to evaluate Mill's proposal to grant extra weight to the votes of (some) university-educated citizens. Estlund argues that it would be reasonable to levy a "demographic objection" against this proposal, according to which "[t]he educated portion of the populace may disproportionately have epistemically damaging features that countervail the admitted epistemic benefits of education" (Estlund 2008, p. 215). Estlund does not argue that this is a decisive, undeniable objection to plural voting; rather, he embraces the more modest claim that, in light of this objection, there could be reasonable disagreement on whether plural voting advances the cause of justice. He goes on to argue that because "[i]t is a matter on which there will be reasonable disagreement...[it] is fatal to the proposal to use [this] position in justifying political arrangements" (Estlund 2008, p. 222). Estlund, then, agrees with my Disagreement-Sensitive Deviation Principle: a deviation from ordinary democratic procedures is only justified if the argument for that deviation is beyond reasonable disagreement. 
Now, as Kolodny himself points out (2014a, p. 224), Estlund is never clear about why he thinks democracy enjoys a special default status, making deviations from it so difficult to justify. ${ }^{\text {xxvi }}$ However, our respect-based argument furnishes a compelling reason as to why: because democracy respects the moral agency of citizens. So long as democratic citizens are pursuing objectively reasonable views about what justice requires, they are deploying their first moral power successfully. They are doing their morally assigned job, as part of their collective mission to realize justice. And so they rightly take themselves to be disrespected when they suddenly find themselves excluded from that mission.

\section{The ethics of judicial review}

Democracy respects the first moral power of citizens. It recognizes that the job of achieving a just society belongs to all moral agents who are members of that society, in light of their common possession of the natural duty of justice. In this section I apply this argument to one of the most significant ongoing debates in democratic theory: the debate over whether judicial review is morally objectionable. By judicial review, I am referring to rights-based judicial review of democratic legislation: the legal practice according to which "appointed judges have the power to declare enactments of legislatures and other representative institutions void because they offend constitutional guarantees of individual rights" (Dworkin 2006, p. 255). My limited aim in this section is to show how the respect-based argument helps us better understand a certain familiar complaint about judicial review: that it undemocratically supplants the considered will of the democratic public with the political convictions of judicial elites. Specifically, the respect-based argument shows when this complaint is plausible, when it is implausible, and why. In so doing, it points toward a middle course between the two stark poles that typify the scholarly debate on judicial review. 
The most influential argument for judicial review in the scholarly literature is advanced by Ronald Dworkin, who defends the practice on instrumental grounds. On his view, justice is more likely to be achieved in an institutional structure that contains judicial review than in one without it (1996, p. 34). "The United States," he writes, "is a more just society than it would have been had its constitutional rights been left to the conscience of majoritarian institutions" $(1986$, p. 356$){ }^{\mathrm{xxvii}}$ And the reason why judicial review succeeds in advancing the cause of justice is that this is precisely what judges rightly take their job to be. For Dworkin, so long as judges' decisions are consistent with precedential interpretations of the constitutional text, they ought to be guided by their vision of what the correct conception of justice is. Rawls astutely encapsulates this Dworkinian ethic of judging, arguing that judges who undertake judicial review should "appeal to the political values they think belong to the most reasonable understanding of the public conception and its political values of justice and public reason" (2005, p. 236, emphasis added).

Waldron offers the most influential criticism of this position. Given that people disagree about what justice demands, there is no shared basis for the judgement that judicial review advances, rather than sets back, its cause. When a constitutional court decides to strike down a piece of popular legislation, the majority of citizens who supported that legislation will view this decision as an unwarranted replacement of their own convictions about justice with the preferences of a judicial elite. In permitting such replacements, judicial review "disenfranchises ordinary citizens and brushes aside cherished principles of representation and political equality in the final resolution of issues about rights" (2006, p. 1353).

The respect-based argument illuminates this debate by showing where each position goes right, and where each position goes wrong. Dworkin (alongside Rawls) is committed to the objectionable position that even if a piece of democratic legislation is substantively reasonable - even if it is a plausible interpretation of what justice requires - a judge should 
strike it down as unconstitutional if it deviates from whatever the most plausible interpretation happens to be. Dworkin's ideal judge overrides even reasonable democratic legislation, so long as the right conception of justice is served by such a decision. Whether or not millions of democratic citizens (reasonably) disagree - as they must, given that their legislation is under review-is irrelevant.

The respect-based argument (in its disagreement-sensitive variation) thus condemns Dworkin's position as incompatible with a view of citizens as bearers of the natural duty of justice. Such reasonable disagreements — on matters such as freedom of speech, freedom of religion, and criminal procedure - are, in the first instance, our disagreements to debate and work out. Democracy is the morally default mode of confronting them. Taking a decision out of the hands of democracy is only justified if the argument for such outsourcing is beyond reasonable disagreement. The first part of that argument involves establishing that the experts to granted authority are, in fact, likely to advance the aims of justice. ${ }^{\text {xxviii }}$ But secondly, such aims must themselves be beyond reasonable dispute-i.e., the court must only strike down legislation whose injustice is beyond the pale of reasonable disagreement. The authority of constitutional courts is accordingly constrained. They may not override reasonable legislation simply because they believe (even correctly) that the most reasonable view about justice is served in so doing. Simply because a jurist happens to hold a different reasonable view on a question does not grant her the license to supplant the reasonable, democratically enacted view with her own.

Consider, for example, the 2010 case of Citizens United v. Federal Election Commission. The case turned partly on an interpretation of the ideal of freedom of speech as protected by the First Amendment of the U.S. Constitution, and whether certain campaign finance regulations did or did not offend against that ideal. Let us submit for the sake of argument that there is reasonable disagreement about what free speech demands, permits, or 
prohibits in the matter of campaign finance. Citizens embraced one reasonable view by passing the Bipartisan Campaign Reform Act (BCRA). The majority of U.S. Supreme Court justices disagreed, contending that their view of free speech was the most reasonable, and they accordingly overrode the reasonable democratic will with their own (reasonable) view. Many liberals balked at this decision because they hold that freedom of speech, properly interpreted, is consistent with campaign finance regulation. But this is not the reason why we ought to criticize such a case. If the case was wrongly decided, it is because there is reasonable disagreement about what free speech demands, permits, or prohibits in the matter of campaign finance. In the face of such reasonable disagreement, the right response is to settle the matter democratically — as citizens indeed did when they democratically enacted the Bipartisan Campaign Reform Act (BCRA). It is not the proper job of judges to supplant a reasonable, democratically enacted account of the right to free speech with their own reasonable account.

This rejection of the Dworkinian position retains the spirit of Waldron's criticism, but it differs in three interrelated ways. First, it agrees with Waldron that Dworkin fails to take disagreement seriously, but it emphasizes that the real problem is a failure to take reasonable disagreement seriously, not simply disagreement simpliciter. ${ }^{\text {xxix }}$ Waldron is liable to the charge of equivocation on this point, especially in his earlier writings on this subject. "Legislation deserves respect," Waldron writes, "because of the achievement it represents in the circumstances of politics: action-in-concert in the face of disagreement" (1999, p. 108). Judicial review, he thinks, objectionably short-circuits that democratic achievement. But this argument goes too far. Democratic law-making is not an achievement in all cases. It is only an achievement when the policy enacted is from the set of morally reasonable candidate policies. We should not celebrate any proposed solution to our disagreements over public policy, no matter how morally bankrupt. ${ }^{\mathrm{xxx}}$ 
As a result — and here is the second difference-Waldron's condemnation of judicial review is too sweeping. Certainly, in his earlier writings, Waldron defends the wholesale abolition of judicial review. But if Dworkin's argument is misguided only in the context of reasonable disagreements about justice, it is difficult to see why we should be opposed to a restrained form of judicial review that operates only by striking down legislation whose injustice is beyond the pale of reasonable disagreement. Waldron himself now concedes that judicial review might be morally justified in seriously pathological social contexts $(2006$, p. 1406). ${ }^{\mathrm{xxx}}$ But this proposal errs in suggesting that we have a binary choice: a fully fledged judicial review, operating with full Dworkinian ambition, or none at all. But there is a third option: a limited form of judicial review, operating quietly the background, stepping in only when the democratic polity has transgressed a minimal moral standard of reasonableness. Provided such a proposal can pass the tests for outsourcing specified earlier, citizens have strong moral reason to endorse it.

Finally, the respect-based argument offers a more direct and, I submit, more convincing non-consequentialist story about why judicial elites should not mettle in the reasonable political disagreements of ordinary citizens: it's not their job. ${ }^{\mathrm{xxxii}}$ Rather, it's everyone's job. The task of specifying the demands of justice through law is one that belongs, in the first instance, to all. The sense of outrage citizens routinely experience when reasonable legislation is enacted by the democratic assembly, and then dissolved by the courts, testifies to this core conviction. And the respect-based argument I have defended accounts for why that conviction is justified.

Now it does not follow that we should entrust courts to strike down any and all legislation that falls beyond the pale of reasonable dispute. Three observations are important to make here. First, familiar concerns about the rule of law recommend our present practice, whereby certain fundamental rights are specified in a constitutional text that then anchors 
jurists' deliberations. Here the idea of reasonable disagreement enters the story in two ways. On this account, the rights protected by a constitution should include only those that no one could reasonably deny; rights whose existence (or, if you prefer, justification) is subject to reasonable disagreement are properly left to the ordinary democratic process to recognise or deny ${ }^{\text {xxxiii }}$ Further, in a system so conceived, judges should only strike down legislation when it is beyond reasonable disagreement that the legislation actually violates the right in question.

Second, the fact that a given right is beyond reasonable dispute is necessary but not sufficient for its inclusion on the list of rights to receive judicial protection. The argument for the Disagreement-Sensitive Deviation Principle we specified earlier held that a given instance of outsourcing is justified only when it is beyond reasonable disagreement that the outsourcing will advance justice. But using judicial review may be a poor candidate for advancing justice in certain areas. For example, suppose that it is beyond reasonable disagreement that the state provide welfare benefits for socially deprived citizens. Even so, many suppose that judicial involvement in the provision of welfare rights is counterproductive (Brettschneider 2007, p. 148; Tushnet 2004), failing to advance the protection of these rights. If that is so, then clearly our natural duty of justice should not move us to specify welfare rights as among those the judiciary should be tasked with protecting. So, it goes, too, for legislation predicated on, say, manifestly unreliable economic data. Even if it undeniably unjust, it does not follow that courts should be empowered to strike it down, given the lack of economic expertise of jurists.

Third, a policy could be beyond the pale of reasonable disagreement and yet only constitute a trivial or mild injustice. Suppose that a new democratically enacted regulation requires restaurants to list their dishes on their menus in rough order of those dishes' popularity, and that this is a manifestly silly regulation. I hazard that it would strike most as 
intuitive that such legislation, however foolish, should not be struck down by a court. The appropriate remedy in such a situation would be for democratic citizens to reconsider the statute and alter it accordingly. But why? Why not simply accept that courts ought to be empowered to strike them down? This possibility is not, strictly speaking, precluded by the argument here. But there are reasons to suppose that judicial review ought to be restricted not simply to striking down injustices, but injustices of a sufficient seriousness. These reasons concern the costs of permitting the judiciary to strike down trivially unjust legislation. In part, these costs consist in worries about clogging court dockets with complaints against policies that, while wrongful, are best resolved by pressuring the legislature to revisit the issue and alter its stance. But the costs may run even deeper. Given that democracies are likely to make trivial albeit undeniable mistakes from time to time, constant interference by the courts may have a deleterious affect on the democratic process. Some scope for making mistakes is indispensable, we might think, for a democracy staffed by fallible citizens. ${ }^{\text {xxxiv }}$ Some latitude to make mistakes might well be necessary for the democratic process to function effectively with respect to its central aim: advancing just government.

In principle, we ought to be open to all of these concerns; I bring them up here simply to note that a complete account of judicial review would need to attend to them. But notice: these concerns are instrumental, centrally concerned with the advancement of substantive justice. They do not rely on the thought that the democratic decision, albeit undeniably unjust, has intrinsic value in virtue of its majoritarian credentials. Registering an insight that I suspect is widely shared, Corey Brettschneider notes: "If persons in a democracy have the status of rulers, there should be some merit to considering what they actually think when it comes to ruling" (2007, p. 143); that, he thinks, explains why trivial injustices should not be overridden (p. 148). But the respect-based argument politely dissents. While I would agree that the democratic status of a decision grants it prodigious prima facie merit, such status is 
merely prima facie. It is not pro tanto. Insofar as citizens felt disrespected when a court struck down a manifestly stupid policy, this reaction would only be justified by appealing to the costs mentioned above. Simply insisting on the intrinsic value of political autonomy, no matter what that autonomy is used to do, is insufficient, for the very point of democracy—of granting political autonomy to all as equals - is to enable us to do our job in advancing the cause of justice. ${ }^{\mathrm{xxv}}$ We undercut that rationale when we enact injustice, even when it is trivial. To be sure, many agents who pursue injustice do not believe they are pursuing injustice. That makes them less blameworthy than those who pursue justice intentionally. But it makes no difference to permissibility of their actions, or our responses to them, at least in standard cases. We do not wrong individuals, even as a pro tanto matter, when we prevent them from culpably perpetrating undeniable injustice. That is so whether or not they recognize that what they are doing is wrong. ${ }^{\text {xxxvi }}$

It is important to recognize that my thesis - that judicial review ought to proceed in a spirit of restraint, restricting itself to the task of overriding undeniable injustice-is continually defied by contemporary judicial practice, especially in the United States. But it is hardly a novel suggestion. Felix Frankfurter defended something like this approach (even if I disagree with how he applied it) from the bench of the U.S. Supreme Court. In his concurring opinion in Dennis v. United States, he argued that the Court ought "to set aside the judgment of those whose duty it is to legislate only if there is no reasonable basis for it" (United States Supreme Court 1951). The suggestion has had its defenders in political philosophy, too. Thomas Christiano argues that only "core" exercises of individual rights should be judicially protected, leaving peripheral cases for democratic decision-making (Christiano 2008, pp. 136ff). Laura Valentini similarly distinguishes between concerns of "fundamental justice," which ought to be constitutionally protected, and non-fundamental concerns that ought to be left to democratic citizens to decide (2013, pp. 180-181). And Gerald Gaus argues that 
allowing the judiciary to weigh in on contestable political disputes is "to erect the Court into a quasi-guardian." He thus concludes: "Judicial review is justified, but in general courts ought to be deferential to legislatures" (1996, p. 283).

What makes my defence of a minimalist position unique is the way it is grounded in a relatively straightforward story about democracy's value. It does not rely on Thomas Christiano's complex defense of democracy as the best means for publicly advancing the equal interests of all in conditions of disagreement and fallibility. It does not rely on Gaus's framework of justificatory liberalism, according to which public justification proceeds with reference to the (partly idealized versions of) actual beliefs of real citizens. And while it agrees with Valentini and many others that the key to justifying democracy is respect for persons, it denies that the intrinsic suitability of democracy depends upon the existence of "thick reasonable disagreement" (2013, p. 183). For even if the mission of justice was undeniably obvious - and in many cases, it is - it is a mission that is presumptively assigned to all to complete. Democracy is not simply some institutional response to a certain sort of disagreement. It is recommended as a default rule by the sheer fact of our equal moral agency.

I have argued that the payoff of my respect-based argument is three-fold when applied to the debate over judicial review. First, it explains why the two most famous positions in this debate - that of Ronald Dworkin and Jeremy Waldron - are each implausible. Waldron is right to balk at the expansive role that Dworkin assigns constitutional court judges, but he overcorrects by endorsing the wholesale abolition of judicial review in well-ordered liberal democracies. Second, it justifies a plausible middle ground between these two stark poles, according to which judicial review can be justified, but only when the legislation it condemns is beyond the pale of what anyone could reasonably defend. And finally, it explains why citizens may rightly be insulted by judicial review even in cases when the content of the 
judicial decision is substantively reasonable. For, when the content of the democratic decision is also substantively reasonable, the court has no right to override that decision simply to impose its own preferred reasonable position. To do so constitutes an unjustified deviation from the default rules of a democratic society, in which the job of pursuing justice presumptively belongs to all. 


\section{Notes}

i The language of "insult" is from Mill 1861, Chapter 8, and is employed by Waldron 1999, p. 239.
ii I have assigned each a slogan for heuristic purposes.
iii "The peculiar insult to an individual, A, of A's being excluded from political power," Jeremy Waldron writes,
"has to do, first, with the impact of political decisions on A's own rights and interests" (1999, p. 238). As
Kolodny notes, this view is also advanced by Beitz 1989, p. 110, and Dworkin 2002, p. 200.
iv The suggestion that political exclusion communicates to agents that their capacity for moral reasoning is
inferior is widespread; for just some examples, offered by Kolodny, see Dworkin 1996, p. 28; Waldron 1999, inferior is widespread; for just some examples, offered by Kolodny,
pp. 239-39; Christiano 2010, p. 93; and Richardson 2002, pp. 62-3.

v This duty is discussed in Rawls 1999, pp. 99-100, 115, 293-301, and 334, as well as in Waldron 1993 and Stilz 2009. See also Simmons 1979, pp. 147-52, and Klosko 1994.

${ }^{v i}$ Provided, anyway, that the costs of doing so are not unreasonably burdensome; Rawls 1999, p. 294. I discuss the implications of this proviso later on.

vii See Kant 1965 [1785], sec. 42, p. 71).

viii See Stilz (2009, pp. 44-56) and Ripstein (2009, pp. 145ff).

ix Cf. Howard 2015b.

${ }^{x}$ Democratic rights and responsibilities need not have different bases. Sometimes the reason why agents have certain moral rights to do certain things is that they have duties to do those same things. Rawls calls these enabling rights (2008, p. 144). Enabling rights are discussed in Wenar 2013, pp. 207-08.

${ }^{x i}$ Of course, when one is a victim of injustice, insisting on one's rights just is exercising one's first moral power: advocating for justice.

${ }^{x i i}$ It is an open question whether monetary policy would better serve the aims of justice if made democratically.

xiii As when the U.S. Supreme Court decided arrogate authority to itself that they were originally not conferred by the democratic polity, in Marbury v. Madison 5 U.S. 137 (1803).

xiv I thank an anonymous reviewer for pressing this objection.

${ }^{x v}$ This idea is a recurrent one throughout Shelby 2015.

${ }^{x v i}$ For the idea of subversion, see Howard 2015 b.

xvii This is not to suggest that the value of such structures is only instrumental. As Eric Beerbohm notes, "The distinction between intrinsic and instrumental goods does not cut at the joint of value" (2008, p. 34). We can value democracy noninstrumentally without believing that democratic procedures contain intrinsic value, no matter how they are used. Beerbohm contends that democracy is noninstrumentally valuable because of "the relationships among cocitizens that honoring its rules makes possible" (p. 36). What makes these relationships valuable? Beerbohm's answer is "the root contractualist idea that we care about standing in relations of recognition or coanswerability with each other" (pp. 38-39). In place of this claim, I have argued for the simpler claim that democracy is valuable because it enables agents to live up to their moral duties. This is a distinct argument than Beerbohm's argument based on "relations of recognition or co-answerability", which does not explicitly invoke the natural duty of justice; but it is certainly in the same family of approaches to democracy's value.

xviii Unfortunately for Rawls, his account of the burdens of judgment gives support for both the subjectivist and the objectivist accounts of reasonable disagreement (Rawls, pp. 56-57). But the slavery example shows that the subjectivist account cannot be right.

xix Though this fact may bear on the appropriate degree of blame or punishment she deserves.

${ }^{x x}$ In his definitive treatment of objectively reasonable disagreement, Christopher McMahon writes: "[T]he position taken by a party to a disagreement is reasonable if and only if it is or could be the product of competent reasoning." He continues: "Reasoning is competent when it is carried out in awareness of all the relevant considerations, the cognitive capacities exercised in extracting conclusions from the relevant considerations are appropriate, and these capacities are functioning properly" $(2009$, p. 8).

xxi Locke's discussion blends reasonable disagreement with independent worries about how self-interest can corrupt agents' judgment.

xxii In fact, Kant believes that agents are morally entitled to do so-to do "what seems right and good" to him or her $(\S 44)$. But we need not embrace that radical view here.

xxiii See the instructive discussion of this issue in Waldron 1996, pp. 1538-40.

xxiv Quong, Liberalism Without Perfection, p. 133.

${ }^{\mathrm{xxv}}$ How do we decide what is a reasonable position in a debate? It is tempting to demand algorithmic precision on this matter, but none is, or can be, forthcoming. The determination that a given disagreement is reasonable will depend on a substantive judgment, which can only be made by examining the arguments on all sides- by 
determining whether the premises of each side are plausible and the chains of reasoning valid, despite arriving at opposed conclusions.

xxvi For further critical discussion of Estlund, see Howard 2015a.

xxvii Similar considerations underwrote Dworkin's efforts to advocate for the power for the UK Supreme Court to strike down acts of Parliament (1990).

xxviii Clearly it is beyond the scope of this article to establish whether the U.S. Supreme Court, for example, satisfies this test.

xxix This stands in contrast to Richard Bellamy, who is consistent in arguing that it is reasonable disagreement about justice, rather than disagreement simpliciter, that explains the lack of legitimacy of judicially enforced constitutional provisions (2007, pp. 20ff). See also David Enoch (2006, pp. 23-25).

${ }^{\mathrm{xxx}}$ It is important to recognize that, in more recent work, Waldron has qualified his argument. He advances a set of assumptions that must hold in order for his rejection of judicial review to succeed. Notable among these assumptions is the existence of a widespread "commitment to rights" among citizens of the democratic polity (2006, p. 1364). But he never specifies this to mean "committed to reasonable views about rights." A society in which opposing parties cast their arguments in the language of rights seems to satisfy Waldron's assumptioneven though plenty of flagrantly unreasonable political positions can be described using rights-talk (such as when citizens justify banning gay marriage on grounds of religious freedom, or justify slavery with the language of property rights). That Waldron oscillates between talk of "good faith disagreement about rights" (p. 1360), brute "disagreements about rights" (p. 1360), and "reasonable disagreements that are inevitable among people who take rights seriously" (p. 1369) raises, at the very least, an interpretive worry that his rejection of judicial review has an implausibly wide scope, even in the later work.

xxxi This suggestion also made by Richard Bellamy (2007, p. 249ff), though he is skeptical that judicial review would function successfully in seriously pathological political environments.

xxxii Or, more accurately, it's their job only in their capacities as ordinary citizens, not in their capacities as judges.

xxxiii One way of interpreting the project in Brettschneider 2007 is to specify the fundamental rights that are beyond reasonable disagreement, which include rule of law protections (pp. 38-44), freedom of speech and conscience (pp. 44-52), rights to privacy (pp. 71-95), and rights against capital punishment (pp. 108-112). Of course, to say that these rights' existence is beyond reasonable disagreement is not to say that there cannot be reasonable disagreement about the particular implications of these rights, or about the kinds of institutions most capable of protecting them.

xxxiv A similar insight is at the heart of Joseph Raz's philosophy, which holds that we sometimes ought not to interfere with individuals' flagrantly irrational choices since doing so would undermine the development of their rational capacities. See Raz 2006 (pp. 1015ff).

${ }^{\mathrm{xxxv}}$ As Eric Beerbohm notes, the fact that an injustice was democratically authorized may aggravate its wrongness $(2012$, p. 36).

xxxvi Of course, if an agent is blamelessly ignorant, this may affect the kinds of actions that one may undertake to stop her from doing wrong, as well as affecting appropriate levels of censure.

\section{Acknowledgments}

I am grateful to Robert Goodin, Leslie Green, David Miller, Paul Bou-Habib, Jonathan

Quong, and Jeremy Waldron for helpful comments.

\section{Disclosure statement}

No potential conflict of interest was reported by the author

\section{Notes on contributor}


Jeffrey $\boldsymbol{W}$. Howard is Lecturer in Political Theory and Normative Methods in the Department of Political Science at University College London. Aside from democratic theory, he teaches and writes on ethics and public policy, focusing on the ethics of counterterrorism and criminal justice policy. He has published in Law and Philosophy, Political Studies, Criminal Law and Philosophy, The Journal of Applied Philosophy, and The Journal of Political Philosophy.

\section{References}

Arneson, R. 2004. "Democracy is Not Intrinsically Just." In: K. Dowding, et al., Justice and Democracy. Cambridge: Cambridge University Press.

Beerbohm, E., 2012. In Our Name: The Ethics of Democracy. Princeton: Princeton University Press.

Beitz, C. 1989. Political Equality. Princeton: Princeton University Press.

Bellamy, R. 2007. Political Constitutionalism. Cambridge: Cambridge University Press.

Brettschneider, C. 2007. Democratic Rights: The Substance of Self-Government. Princeton: Princeton University Press, 2007.

-2011. "Judicial Review and Democratic Authority: Absolute vs. Balancing Conceptions." Journal of Ethics and Social Philosophy, 1, 1-9.

Christiano, T. 2008. The Constitution of Equality: Democratic Authority and Its Limits, Oxford: Oxford University Press.

Dworkin, R. 1986. Law's Empire. Oxford: Hart Publishing.

—1990. A Bill of Rights for Britain, London: Chatto \& Windus.

-1996. Freedom's Law: The Moral Reading of the American Constitution. Cambridge: Harvard University Press.

—2002. Sovereign Virtue. Cambridge, Mass.: Harvard University Press.

Enoch, D. 2006. "Taking Disagreement Seriously: On Jeremy Waldron's Law and Disagreement." Israel Law Review, 39, 22-35.

Estlund, D. Democratic Authority: A Philosophical Framework, Princeton: Princeton University Press, 2008.

Gerald G. F. 1996. Justificatory Liberalism: An Essay on Epistemology and Political Theory. New York: Oxford University Press. 
Goodin, R.E. 1988. "What's So Special about Our Fellow Countrymen?" Ethics, 98, 663686.

Howard, J.W. 2015. "Democracy as the Search for Justice: A Defence of the Democracy/Contractualism Analogy.” Political Studies, 63, 259-275.

Howard, J.W. 2015. "Moral Subversion and Structural Entrapment." Journal of Political Philosophy, 24, 24-46.

Kagan, S. 1989. The Limits of Morality. Oxford: Clarendon Press.

Kant, I. [1785] 1965. The Metaphysical Elements of Justice, trans. John Ladd. Indianapolis: Bobbs-Merrill.

Klosko, G. 1994. "Political Obligation and the Natural Duties of Justice." Philosophy \& Public Affairs, 23, 251-270.

Kolodny, N. 2014. "Rule Over None I: What Justifies Democracy?" Philosophy \& Public Affairs, 42, 195-229.

-2014. "Rule Over None II Social Equality and the Justification of Democracy." Philosophy \& Public Affairs, 42, 287-336.

McMahon, C. 2009. Reasonable Disagreement: A Theory of Political Morality. Cambridge: Cambridge University Press.

Mill, J.S. [1861] 1978. On Liberty. Indianapolis, IN: Hackett Publishing.

Miller, D. 1995. On Nationality. Oxford: Oxford University Press.

Nagel, T. 2005. “The Problem of Global Justice.” Philosophy \& Public Affairs, 33, 113-147.

Quong, J. 2010. Liberalism Without Perfection. New York: Oxford University Press.

Rawls, J. [1971] 1999. A Theory of Justice, revised edition. Cambridge. MA: Harvard University Press.

-2000. Lectures on the History of Political Philosophy. Cambridge, MA: Harvard University Press.

-2001. The Law of Peoples. Cambridge, MA: Harvard University Press.

— [1993] 2005. Political Liberalism. New York: Columbia University Press.

Raz, J. 1986. The Morality of Freedom. Oxford: Oxford University Press.

Richardson, H. S. 2002. Democratic Authority: Public Reasoning about the Ends of Policy. Oxford: Oxford University Press. 
Ripstein, A. 2009. Force and Freedom. Cambridge, MA: Harvard University Press.

Sangiovanni, A. 2007. "Global Justice, Reciprocity, and the State." Philosophy \& Public Affairs, 35, 3-39.

Shelby, T. 2015. Dark Ghettos: Injustice, Dissent, and Reform. Cambridge, MA: Harvard University Press.

Shiffrin, S.V. 2000. "Paternalism, Unconscionability Doctrine, and Accommodation." Philosophy \& Public Affairs, 29, 205-250.

Simmons, A.J. 1979. Moral Principles and Political Obligation. Princeton: Princeton University Press.

Stilz, A. 2009. Liberal Loyalty: Freedom, Obligation, and the State. Princeton: Princeton University Press.

Valentini, L. 2013. "Justice, Disagreement, and Democracy." British Journal of Political Science, 43, 177-199.

Waldron, J. 1999. Law and Disagreement. New York: Oxford University Press.

-1993. "Special Ties and Natural Duties.” Philosophy \& Public Affairs, 22, 3-30.

—1996. “Kant’s Legal Positivism.” Harvard Law Review, 109, 1535-1566.

—2006. "The Core of the Case against Judicial Review." Yale Law Journal, 115, 1346-1406.

Wenar, L. 2013. “The Nature of Claim-Rights.” Ethics, 123, 202-229. 